\title{
Nodulation of Mimosa spp. by the $\beta$-Proteobacterium Ralstonia taiwanensis
}

\author{
Wen-Ming Chen, ${ }^{1}$ Euan K. James, ${ }^{2}$ Alan R. Prescott, ${ }^{2}$ Martin Kierans, ${ }^{2}$ Janet I. Sprent ${ }^{3}$ \\ ${ }^{1}$ Laboratory of Microbiology, Department of Seafood Science, National Kaohsiung Institute of Marine Technology, Kaohsiung \\ City 811, Taiwan; ${ }^{2} \mathrm{CHIPs}$, MSI/WTB Complex, School of Life Sciences, University of Dundee, Dundee DD1 5EH, U.K.; \\ ${ }^{3}$ Division of Environmental and Applied Biology, School of Life Sciences, University of Dundee, Dundee DD1 4HN, U.K.
}

Submitted 6 May 2003. Accepted 1 August 2003.

Several $\beta$-proteobacteria have been isolated from legume root nodules and some of these are thought to be capable of nodulating and fixing $\mathrm{N}_{2}$. However, in no case has there been detailed studies confirming that they are the active symbionts. Here, Ralstonia taiwanensis LMG19424, which was originally isolated from Mimosa pudica nodules, was transformed to carry the green fluorescent protein $(g f p)$ reporter gene before being used to inoculate axenically-grown seedlings of $M$. pudica and $M$. diplotricha. Plants were harvested at various intervals for $\mathbf{5 6}$ days after inoculation, then examined for evidence of infection and nodule formation. Nodulation of both Mimosa spp. was abundant, and acetylene reduction assays confirmed that nodules had nitrogenase activity. Confocal laser scanning microscopy (CLSM) showed that fresh $M$. pudica nodules with nitrogenase activity had infected cells containing bacteroids expressing $g f p$. In parallel, fixed and embedded nodules from both $\mathrm{Mi}$ mosa spp. were sectioned for light and electron microscopy, followed by immunogold labeling with antibodies raised against $g f p$ and nitrogenase $\mathrm{Fe}$ (nifH) protein. Significant immunolabeling with these antibodies confirmed that $R$. taiwanensis LMG19424 is an effective $\mathrm{N}_{2}$-fixing symbiont of Mimosa spp. Both species were infected via root hairs and, in all respects, the nodule ontogeny and development was similar to that described for other mimosoid legumes. The nodules were indeterminate with a persistent meristem, an invasion zone containing host cells being invaded via prominent infection threads, and an $\mathrm{N}_{2}$-fixing zone with infected cells containing membrane-bound symbiosomes.

Additional keywords: immunogold labeling.

Until recently, it has been generally accepted that legumes (and the nonlegume genus Parasponia) are nodulated exclusively by members of the family Rhizobiaceae in the $\alpha$-proteobacteria, which includes the genera Azorhizobium, Bradyrhizobium, Mesorhizobium, Rhizobium, and Sinorhizobium (Sprent 2001). In the last few years, however, a number of other $\alpha$-proteobacteria have been shown to nodulate legumes (Moulin et al. 2002). These include strains of Methylobacterium that nodulate Crotalaria and Lotononis (Jaftha et al. 2002; Sy et al. 2001a and b); Blastobacter denitrificans, which nodulates Aeschynomene in-

Corresponding author: E. K. James, Telephone: +44 1382 344741; Fax: +44 1382 345893; E-mail: e.k.james@dundee.ac.uk

*The Spotlight logo represents articles that, in the opinion of the senior editor and editor-in-chief, are of special interest to a broad readership. dica (van Berkum and Eardly 2002); and Devosia strains that nodulate Neptunia natans (Rivas et al. 2002). More controversially, a few members of the $\beta$-proteobacteria, such as Burkholderia sp. strains STM678 and STM815 (originally isolated from Aspalathus carnosa and Machaerium lunatum, respectively; Moulin et al. 2001) and Ralstonia taiwanensis LMG19424 (isolated from Mimosa pudica; Chen et al. 2001) have been discovered in nodules of tropical legumes. The Mimosa nodule isolates were originally placed in the genus Ralstonia primarily on the basis of their 16S rDNA sequences, and this was followed by a polyphasic taxonomy study in which comparisons were made with other Ralstonia spp. using DNA-DNA hybridizations, DNA base ratio determinations, amplified $16 \mathrm{~S}$ rDNA restriction analyses, whole cell protein analyses, and extensive biochemical tests. It was concluded from this thorough study that the Ralstonia isolates belonged to a new species, $R$. taiwanensis (Chen et al. 2001). Similarly, the Burkholderia nodule isolates described originally by Moulin and associates (2001) primarily on the basis of their 16S rDNA sequences have since been shown by a polyphasic taxonomy to be in the newly described species, Burkholderia tuberum (STM678) and B. phymatum (STM815) (Vandamme et al. 2002).

Although these $\beta$-proteobacteria strains are suspected to be capable of nodulating and fixing $\mathrm{N}_{2}$ in their respective host plants, there have been no detailed studies confirming that they are the active symbionts, and there is no information about their modes of infection. Indeed, to date, the only evidence that any of them can form nodules comes from the study by Moulin and associates (2001), in which it was shown that Burkholderia sp. strains STM678 and STM815 could produce ineffective nodules on the promiscuous legume Macroptilium atropurpureum. The green fluorescent protein ( $g f p)$ reporter gene (Chalfie et al. 1994) can be used to examine unfixed tissue in real time and without the addition of substrates and, therefore, has been a powerful tool in following the processes involved in the formation and function of legume symbioses (Cheng and Walker 1998; Gage et al. 1996; Xi et al. 1999). Therefore, in the present study, the type strain of $R$. taiwanensis, LMG19424, was transformed to carry gfp (Table 1) before being used to inoculate axenically grown seedlings of Mimosa pudica L. and $M$. diplotricha C. Wright ex Sauvalle var. diplotricha (syn. M. invisa var. inermis Adelb.). The plants were harvested at intervals over a period of 56 days after inoculation, and examined using confocal laser scanning microscopy (CLSM) as well as light microscopy and electron microscopy (EM) coupled with immunogold labeling with antibodies against $g f p$ and nitrogenase $\mathrm{Fe}($ nifH) protein. The combined use of these techniques has provided very strong evidence for infection of Mimosa spp. by R. taiwanensis and the subsequent 
formation of effective $\mathrm{N}_{2}$-fixing nodules; thus, this is the first study to show definitively that a $\beta$-proteobacterium can enter into a functional symbiosis with legumes.

\section{RESULTS}

\section{Growth, nodulation, and $\mathbf{N}$ fixation.}

The $g f p$ transconjugant strain of $R$. taiwanensis, 204 (Table 1), showed no sign of phenotypic changes relative to strain LMG19424 on either liquid or solid media, and whole-cell protein profiles, ARDRA, and BIOLOG analyses (results not shown) gave identical results with both strains. Strain 204 fluoresced at the correct wavelength for $g f p$ (Fig. 1A and B), whereas the parent strain, LMG19424, did not fluoresce (results not shown). Both Mimosa spp. nodulated after inoculation with $R$. taiwanensis under sterile conditions, and the number of nodules per plant (e.g., on $M$. pudica; Table 2) did not differ significantly between plants infected with the wild-type or the $g f p$-transformed strain. The plants grew well without added $\mathrm{N}$ and, by 56 days after inoculation, both $M$. diplotricha and $M$. pudica had woody stems with spines (Fig. 1C and D). The two species generally were similar in their growth habits (i.e., prostrate growth), but they differed in that $M$. diplotricha stems were longer and thinner than those on $M$. pudica, and also in that the pulvinar leaves of $M$. diplotricha were less sensitive to disturbance.

Fresh nodules from $M$. diplotricha and $M$. pudica were examined under the light microscope and, by 21 days, the mostly spherical nodules were sufficiently developed to be visibly pink when cut open (Fig. 1E), thus suggesting that they contained leghemoglobin (Lb). More mature nodules (e.g., at 56 days) were elongated, with a distinct meristem at the tip, a large, pink infected zone, and a senescent zone at the base (Fig. $1 \mathrm{~F})$. Curled root hairs often were associated with the young nodules (Fig. 1E and $\mathrm{G}$ ). Acetylene reduction assays of the plants at 21 and 56 days after inoculation confirmed that they had substantial nitrogenase activities (i.e., $0.051 \mu \mathrm{mol}$ of $\mathrm{C}_{2} \mathrm{H}_{4}$ plant ${ }^{-1} \mathrm{~h}^{-1}$ for $M$. pudica at 21 days, $0.832 \mu \mathrm{mol}$ of $\mathrm{C}_{2} \mathrm{H}_{4}$ plant $^{-1}$ $\mathrm{h}^{-1}$ for M. diplotricha at 56 days, and $4.464 \mu \mathrm{mol}$ of $\mathrm{C}_{2} \mathrm{H}_{4}$ plant $^{-1} \mathrm{~h}^{-1}$ for $M$. pudica at 56 days). Using CLSM, nodules from plants with nitrogenase activity were shown to have infected cells that fluoresced at the appropriate wavelength for $g f p$ (Fig. 1H and I), thus suggesting that they were infected by the $g f p$-tagged $R$. taiwanensis 204. Further evidence for this came from Western blots using an antibody raised against $g f p$. Extracts from free-living strain 204 and extracts of bacteroids from Mimosa nodules infected by strain 204 gave a signal with the $g f p$ antibody (Fig. 2), whereas no signal was obtained with the corresponding extracts from the wild-type strain (LMG19424). Additionally, serial sections of fixed and embedded $M$. pudica nodules infected by strain 204 were strongly immunogold labeled with an antibodies raised against gfp (Fig. $3 \mathrm{~A}$ and $\mathrm{B}$ ) and the nifH protein (Fig. 3C and D), but nodules from plants infected by the wild-type strain gave no signal with the $g f p$ antibody (although they did show a signal with the nifH antibody; data not shown). The nonimmune serum negative control sections gave no significant signal (Fig. 3E and F).

\section{Root infection and nodule structure.}

The early stages ( 5 to 15 days) of the interaction between $R$. taiwanensis and the two Mimosa spp. were examined by light microscopy and EM. From 5 days, distorted and curled root hairs were abundant on roots of both species (Fig. 4A to C), and these often were associated with large bacterial populations attached in a polar manner to the roots (Fig. 4D). At a similarly early stage ( 5 days), nodule primordia were seen to be developing within the roots (Fig. 5A), and these primordia usually were associated with curled root hairs (Fig. 6A). The latter were shown to contain infection threads by light microscopy and transmission electron microscopy (TEM) (Fig. 5B through D), with the bacteria both on the root surfaces adjacent to the infected root hairs (Fig. 5B) and within the root hairs themselves, strongly expressing $g f p$ (Fig. 5E and F). Macroscopically visible primordia could be seen by 10 days on both Mimosa spp. (e.g., on M. pudica; Fig. 6A). At this stage, the primordia consisted of a spherical mass of meristematic tissue with no obvious penetration of the central tissue by the invading bacteria, which were still confined within infection threads that had yet to penetrate beyond the outer cell layers of the root epidermis (Fig. 5D). However, by 15 days, the nodule primordia contained numerous infection threads that had penetrated the newly formed cells and released bacteria into them (Fig. $6 \mathrm{~B}$ and $\mathrm{C})$. Also by 15 days, the larger nodules $(>0.6 \mathrm{~mm})$, although they were still essentially spherical (Fig. 6D), had by now developed a distinct meristem (zone I; Vasse et al. 1990) and invasion zone of cells that were being invaded by infection threads (zone II), and were even shown to be expressing nifH protein in the cells of zone III (Fig. 3C and D). Interestingly, this is a similar size and age to that which nodules on papilionoid legumes, such as Lupinus albus (James et al. 1997) and Lotus uliginosus (James and Sprent 1999), have been shown to express this essential symbiotic protein.

Mature nodules (>30 days) from both Mimosa spp. were typically indeterminate (Figs. $1 \mathrm{~F}$ and $6 \mathrm{E}$ ), with a distinct meristem (zone I), invasion zone (zone II), and infected cells in zone III packed with $\mathrm{N}$-fixing bacteroids (Fig. 6F). In most respects, such as their indeterminate growth and the presence of dark-staining polyphenol- or tannin-containing cells in the nodule parenchyma or cortex (Figs. 3A, C, and E and 6E), the structure of the Ralstonia-infected Mimosa nodules resembled those reported for other mimosoid legumes, such as Acacia spp. (Lopez-Lara et al. 1993; Räsänen et al. 2001), Anadenanthera peregrina (Gross et al. 2002), Leucaena leucocephala (Parveen et al. 1996), Neptunia spp. (James et al. 1992, 2001; Schaede 1940; Subba Rao et al. 1995), and Prosopis (Baird et al. 1985).

Table 2. Number of nodules formed on Mimosa pudica ${ }^{\mathrm{a}}$

\begin{tabular}{lcc}
\hline Strain & 25 DAI & 40 DAI \\
\hline LMG19424 & $10.3 \pm 2.5$ & $32.7 \pm 5.0$ \\
204 & $9.2 \pm 2.5$ & $24.3 \pm 4.2$ \\
\hline
\end{tabular}

${ }^{a}$ At 25 and 40 days after inoculation (DAI) with either wild-type Ralstonia taiwanensis LMG19424 or the green fluorescent protein transconjugant strain 204. Values are means \pm SD of three replicate plants.

Table 1. Bacterial strains and plasmids used in the present study and their origins

\begin{tabular}{lcl}
\hline Bacterial strain or plasmid & Antibiotic resistances & \multicolumn{1}{c}{ Source } \\
\hline Ralstonia taiwanensis LMG19424 & $\mathrm{Km}^{\mathrm{r}} \mathrm{Ap}^{\mathrm{r}} \mathrm{Tc}^{\mathrm{s}}$ & Chen et al. 2001 \\
Escherichia coli S17-1 $\lambda$ pir & $\mathrm{Ap}^{\mathrm{s}} \mathrm{Tc}^{\mathrm{s}} \mathrm{Km}^{\mathrm{s}}$ & de Lorenzo et al. 1990 \\
E. coli $\mathrm{HB} 101$ & $\mathrm{Ap}^{\mathrm{s}} \mathrm{Tc}^{\mathrm{s}} \mathrm{Km}^{\mathrm{s}}$ & Boyer and Roulland-Dussoix 1969 \\
pUTmini-Tn5gfp & $\mathrm{Ap}^{\mathrm{s}} \mathrm{Tc}^{\mathrm{r}}$ & Matthysse et al. 1996 \\
pRK2013 & $\mathrm{Km}^{\mathrm{r}}$ & Ditta et al. 1980 \\
\hline
\end{tabular}

${ }^{\mathrm{a}} \mathrm{Km}=$ kanamycin, $\mathrm{Ap}=$ ampicillin, and $\mathrm{Tc}=$ tetracycline. 

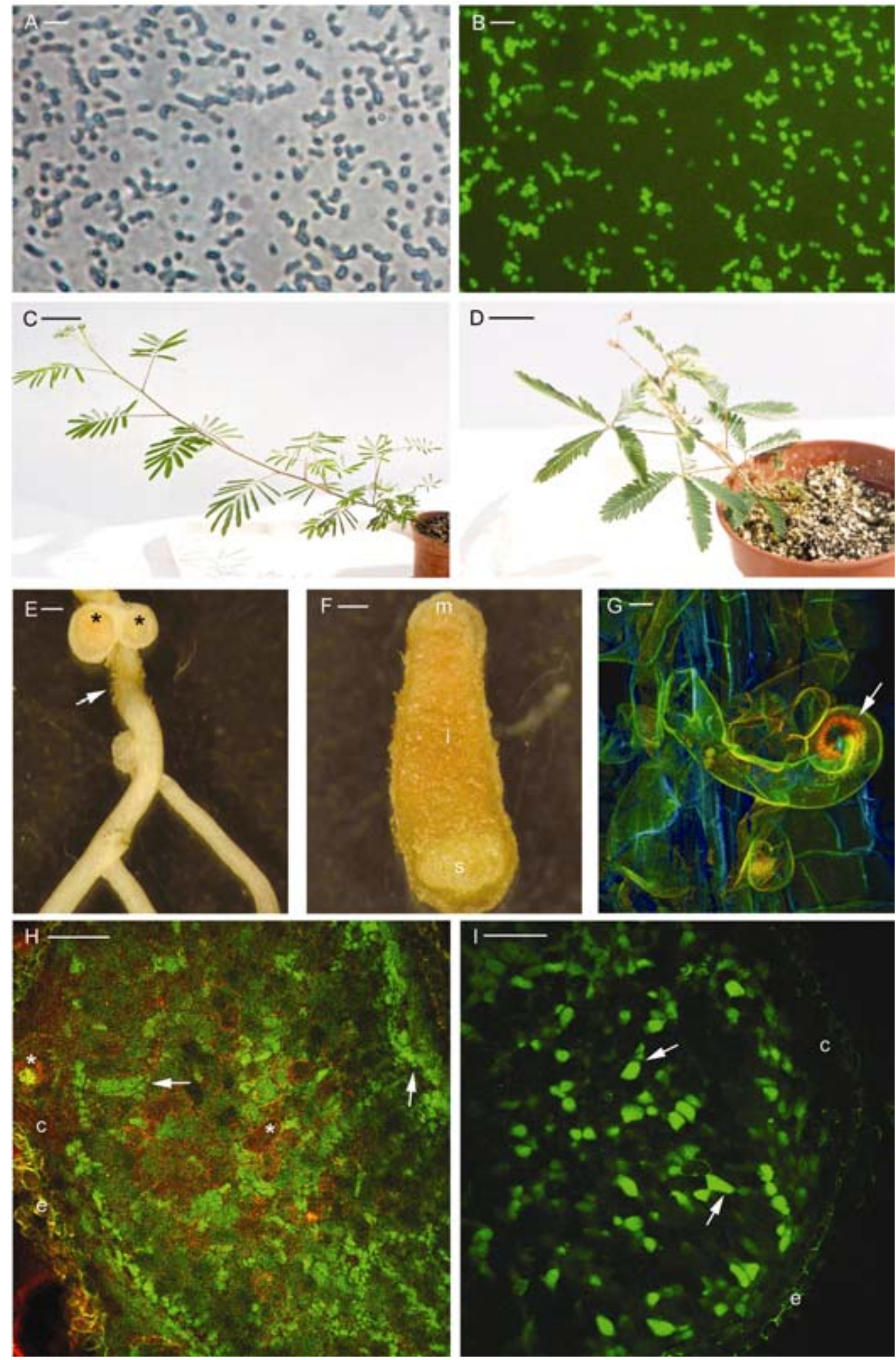

Fig. 1. Ralstonia taiwanensis 204 (the R. taiwanensis-type strain, LMG19424, transformed with plasmid pUTmini-Tn5gfp) A, viewed under phase contrast or B, using a Zeiss no. 9 filter (excitation 450 to $490 \mathrm{~nm}$, emission $>515 \mathrm{~nm}$ ) and a 50-W type HBO high-pressure mercury lamp. C, Mimosa diplotricha and D, M. pudica grown for 56 days in N-free conditions after inoculation with Ralstonia taiwanensis LMG19424. E, Nodules (*), with adjacent root hairs (arrows) on an M. pudica root at 21 days after inoculation, and $\mathbf{F}$, a mature indeterminate nodule at 56 days after inoculation. In both $\mathrm{E}$ and $\mathrm{F}$, the nodules have been sliced open to reveal a pink coloration, indicating that leghemoglobin is present. Note that the nodule in F has a distinct meristem (m) at the tip, a pink infected zone (i), and a senescent zone at the base (s). G through I, Confocal laser scanning microscopy (CLSM) images taken at 488-nm excitation and 515- to 530-nm emission of $M$. diplotricha $\mathbf{G}$, roots and $\mathbf{H}, M$. diplotricha and $\mathbf{I}, M$. pudica nodules after inoculation with $R$. taiwanensis 204 . A curled root hair (arrow) can be seen in $\mathrm{G}$ as a composite of a Z-series projection color-coded for depth where red is nearest to the viewer $(0 \mu \mathrm{m})$ and blue is furthest away $(23 \mu \mathrm{m})$. $\mathbf{H}$ and $\mathbf{I}, \mathrm{Longitu}-$ dinal slices of nodules (56 days) showing high levels of green fluorescence in the cells of the infected zone (arrows) but very little in the uninfected cells of the cortex (c). Note that there is some green autofluorescence from the suberized cell walls of the endodermis (e) in I. The image in $\mathrm{H}$ is a composite of fluorescence obtained from emission through the red and green channels and, therefore, shows yellow autofluorescence $*$ ) in addition to the green fluorescence of the green fluorescent protein reporter gene. The image in I is fluorescence obtained only from the green emission channel. Bar $=2 \mu \mathrm{m}$ in A and B, $20 \mathrm{~mm}$ in C and D, 500 $\mu \mathrm{m}$ in $\mathrm{E}$ and $\mathrm{F}, 10 \mu \mathrm{m}$ in $\mathrm{G}$, and $200 \mu \mathrm{m}$ in $\mathrm{H}$ and $\mathrm{I}$ 


\section{DISCUSSION}

This is the first report that has detailed the infection and nodulation of a legume by a member of the $\beta$-proteobacteria, and is also one of the few studies to date that has examined these processes in members of the genus Mimosa (discussed below). This work has shown that both Mimosa spp. are infected by $R$. taiwanensis via root hairs, and that fully functional, indeterminate nodules capable of expressing nitrogenase are formed within 15 days of inoculation. Strong fluorescence was observed in mature $\mathrm{N}$-fixing nodules infected with a $g f p$-tagged transconjugant of $R$. taiwanensis LMG19424, and immunogold labeling with an antibody against $g f p$ demonstrated that bacteria strongly expressing $g f p$ had accumulated close to curled root hairs, and also that infection threads containing $g f p$-expressing bacteria were present within the root hairs. Furthermore, newly formed nodule primordia adjacent to the infected root hairs contained newly released bacteria that expressed $g f p$, as did the bacteria and bacteroids in mature nodules. Therefore, together with the fluorescence observed under the CLSM and the nitrogenase (acetylene reduction) activity, the significant immunolabeling of the root and nodule sections with the $g f p$ and nifH antibodies has confirmed that $R$. taiwanensis LMG19424 is indeed an effective $\mathrm{N}_{2}$-fixing symbiont of Mimosa spp. This conclusion has been further supported by the recent sequencing by Chen and associates (unpublished data; Moulin et al. 2002) of the nifH, $\operatorname{nod} A, B, C$, and $I$ genes from this bacterium, with all these genes being located on a megaplasmid.

Nodulation in the pantropical genus Mimosa is common and very widely reported (Allen and Allen 1981; Barrios and Gonzalez 1971; Campêlo and Campêlo 1970; de Faria and Lima 1998; de Faria et al. 1987, 1989; James et al. 2001; Moreira et al. 1992; Norris 1969; Sprent 2001; Trinick 1980). It has long been known that $M$. pudica, in particular, is nodulated and that it fixes substantial, albeit variable, quantities of N (Campêlo and Campêlo 1970; Saur et al. 2000; Sicardi de Mallorca and Izaguirre-Mayoral 1993; Sprent et al. 1996). There also have been several previous reports of nodulation of $M$. diplotricha (syn. M. invisa), although less is known about its N-fixing ability (Aguilar et al. 1994; Allen and Allen, 1981; Campêlo and Campêlo 1970; Oyaizu et al. 1993; Trinick 1980). Interestingly, in spite of the propensity of the genus to nodulate, none of the Mimosa spp. tested, including those in the present study ( $M$. diplotricha and $M$. pudica), could be nodulated by the broad host range Rhizobium sp. strain NGR234 (Pueppke and Broughton 1999; Trinick 1980).

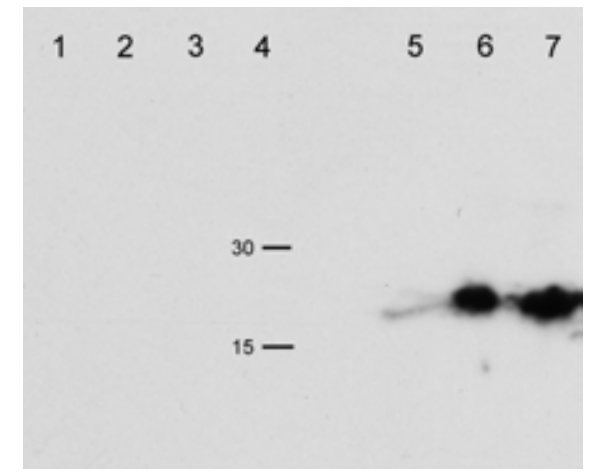

Fig. 2. Western blot of extracts from wild-type Ralstonia taiwanensis LMG19424 (lanes 1 to 3) or the R. taiwanensis green fluorescent protein (gfp) reporter gene transconjugant strain 204 (lanes 5 to 7) probed with an antibody against $g f p$. Lanes 1 and 5 are extracts from free-living bacteria, while lanes 2 and 6 are extracts of bacteroids from Mimosa diplotricha nodules and lanes 3 and 7 are extracts of bacteroids from $M$. pudica nodules. Molecular weight markers (kDa) are in lane 4.
Although nodulated Mimosa spp. are both widespread and abundant, there is a paucity of detailed published information on rhizobial infection and formation of nodules on them. An early study by Lechtova-Trnka (1930) reported infection threads in $M$. dysocarpa nodules, but gave no information about the root infection process, while the study of de Faria and associates (1988) concentrated mainly on the infection process of $M$. scabrella and did not report on the subsequent nodule development. Therefore, the present study is the first one to describe fully the infection and nodule development on any Mimosa spp. Unlike the "direct epidermal" infection reported for M. scabrella (de Faria et al. 1988), both Mimosa spp. studied here clearly had a root hair infection process which, although common among papilionoid legumes, is not always the norm in the other, less well studied legume subfamilies (Sprent 2001). It has been reported previously in the family Mimosoideae for Leucaena leucocephala (Chen and Rolfe 1988) and for some Acacia and Prosopis spp. (Baird et al. 1985; Räsänen et al. 2001), and there also are reports for a root hair infection for the aquatic species Neptunia plena when it is grown under terrestrial conditions (Loureiro et al. 1998). However, in many of the mimosoid legumes so far studied, nonroot-hair-infection processes, such as "crack entry" at lateral root junctions, are commonly found, particularly in aquatic species (James et al. 1992; Loureiro et al. 1998; Schaede 1940; Subba Rao et al. 1995). Indeed, there often is some plasticity in infection processes in many flooding-tolerant legumes which is dependent on inundation. In these cases, root hairs are infected under terrestrial conditions, while crack entry or similar processes occur when the same species is flooded (e.g., Sesbania rostrata [Ndoye et al. 1994], Neptunia spp. [Loureiro et al. 1998], and Lotus uliginosus [James and Sprent 1999]), and it would be interesting to see if $M$. pudica, which is also flooding tolerant (Barrios and Gonzalez 1971; Saur et al. 2000), has a nonroot-hair-infection process with $R$. taiwanensis when its roots are inundated.

Prior to the recent study of Chen and associates (2001), there have been relatively few studies aimed at identifying bacteria from Mimosa nodules and, with the exception of $R$. taiwanensis, all those so far described have been "conventional" $\alpha$-proteobacterial "rhizobia". These include strains from $M$. invisa and $M$. pudica in the Philippines that were related to R. leguminosarum; Rhizobium sp. and B. japonicum (Oyaizu et al. 1993); a novel biovar of Rhizobium etli (bv. mimosae) from $M$. affinis which grows close to fields of common bean (Phaseolus vulgaris) in Mexico (Wang et al. 1999); and strains of Rhizobium sp. from $M$. foliculosa, M. malacocentra, and $M$. polystachya in Brazil (Moreira et al. 1993). However, Chen and associates (2001), in their study of bacteria isolated from $M$. diplotricha and $M$. pudica nodules, discovered that most of their strains ( $94 \%$ of the 180 isolates) were not "rhizobia" at all, but were actually in the newly described genus, Ralstonia (Yabuuchi et al. 1995). The genus Ralstonia is in the $\beta$ proteobacteria and, unlike the closely related genus Burkholderia (Estrada de los Santos et al. 2001), so far has no known diazotrophs apart from Ralstonia taiwanensis. Nonetheless, it is a very diverse genus, with species occupying many diverse environmental and clinical niches (Chen et al. 2001) and, perhaps most relevant for the present study, it includes the important phytopathogen, $R$. solanacearum, which aggressively enters compatible hosts via lateral root cracks and subsequently colonizes xylem vessels (Vasse et al. 1995).

Given the general lack of homologous sequences in other organisms, it is likely that the Mimosa-nodulating Ralstonia strains, as well as the newly discovered nodulating Burkholderia spp., B. tuberum and B. phymatum (Vandamme et al. 2002), obtained their nod genes (particularly the common 

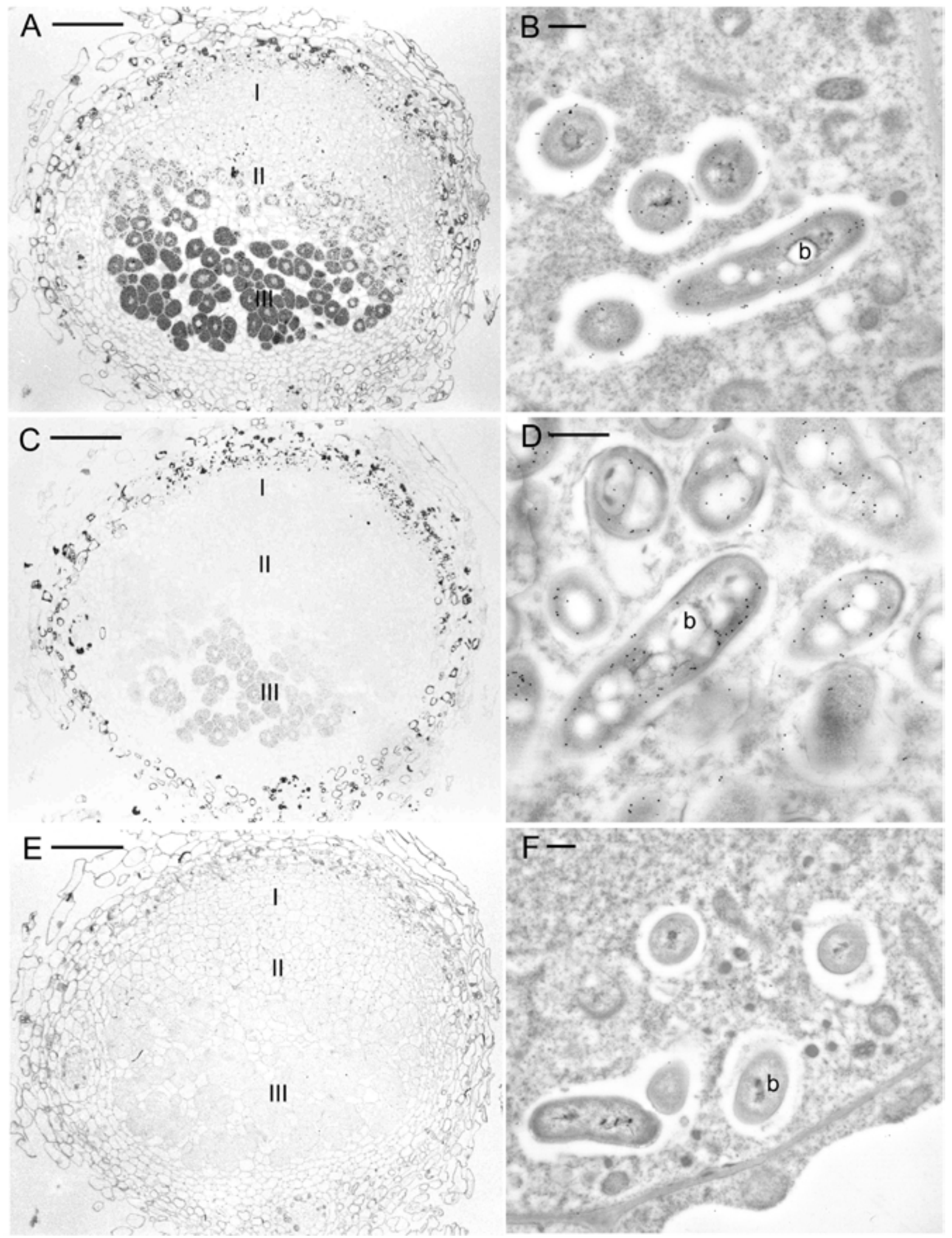

Fig. 3. A, C, and E, Light microscopy and B, D, and F, transmission electron microscopy (TEM) of sections of 15-day nodules from Mimosa pudica plants inoculated with the Ralstonia taiwanensis green fluorescent protein $(g f p)$ reporter gene transconjugant strain 204. The sections were immunogold labeled (A, C, and E followed by silver enhancement) with antibodies either against $g f p$ (A and B) or nitrogenase $\mathrm{Fe}(\mathrm{nifH})(\mathrm{C}$ and $\mathrm{D})$ protein. Although it is young, the nearly spherical nodule already clearly has a meristem (zone I), an invasion zone (II), and an N-fixing zone (III) (closest to the point of attachment with the subtending root). The $g f p$ antibody has labeled strongly both the bacteria within zone II (A) and the bacteroids (b) (A and B) in zone III, whereas the nifH antibody (C and D) only labeled the N-fixing bacteroids. Negative control sections with nonimmune serum (E and F) gave no significant signal. Bar $=100 \mu \mathrm{m}$ in $\mathrm{A}, \mathrm{C}$, and $\mathrm{E}$ and $500 \mathrm{~nm}$ in $\mathrm{B}, \mathrm{D}$, and $\mathrm{F}$. 

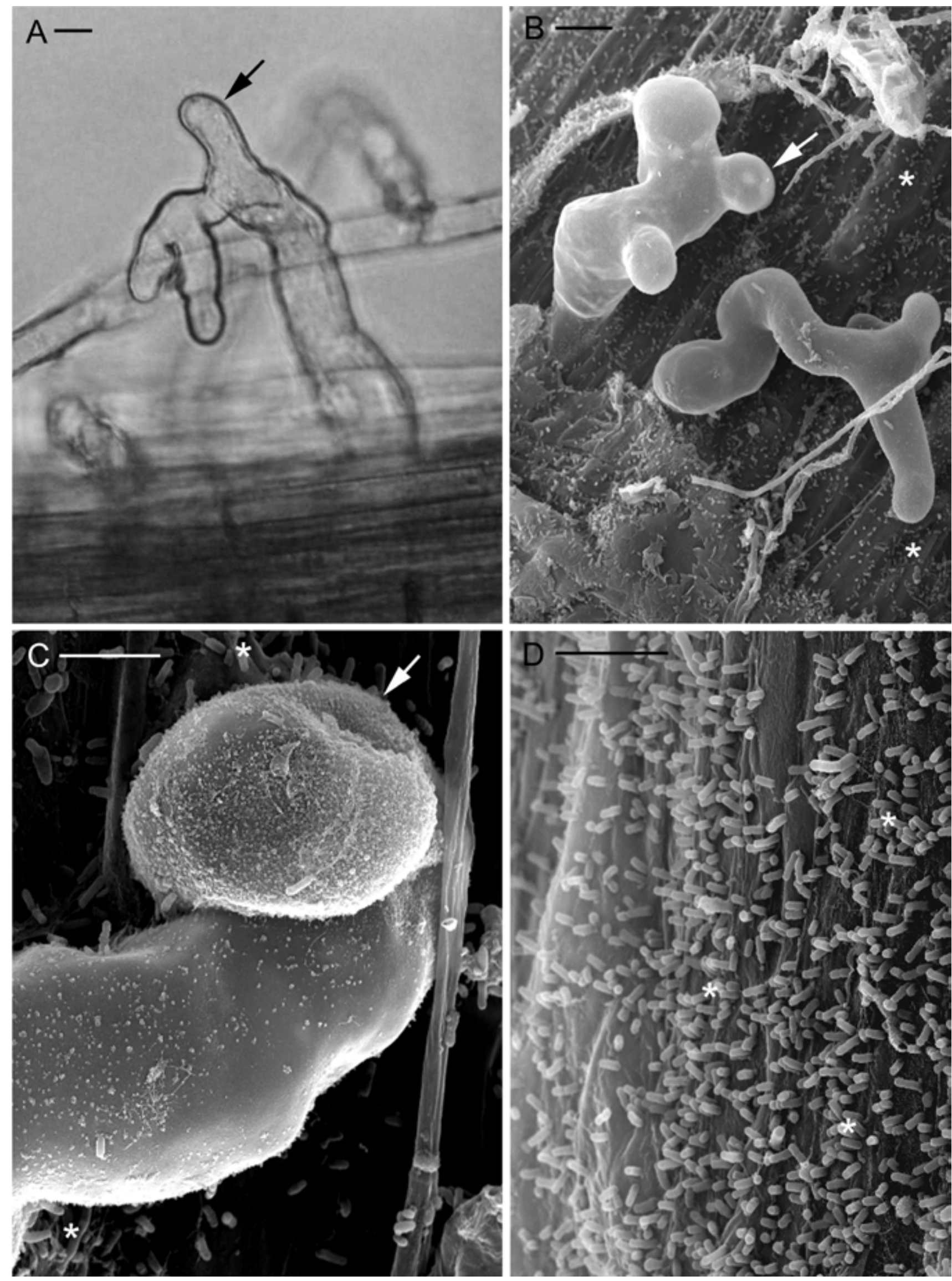

Fig. 4. A, Light microscopy and $\mathbf{B}$ through $\mathbf{D}$, scanning electron microscopy of distorted (A and B) or curled root hairs (C, arrows) associated with dense bacterial colonization (D) on the surface $\left(^{*}\right)$ of roots of Mimosa pudica at 10 days after inoculation with Ralstonia taiwanensis 204. Note that the bacteria in $\mathrm{D}$ are attached to the root surface in a polar manner. Bar $=10 \mu \mathrm{m}$ in $\mathrm{A}$ and $\mathrm{B}$ and $5 \mu \mathrm{m}$ in $\mathrm{C}$ and $\mathrm{D}$. 

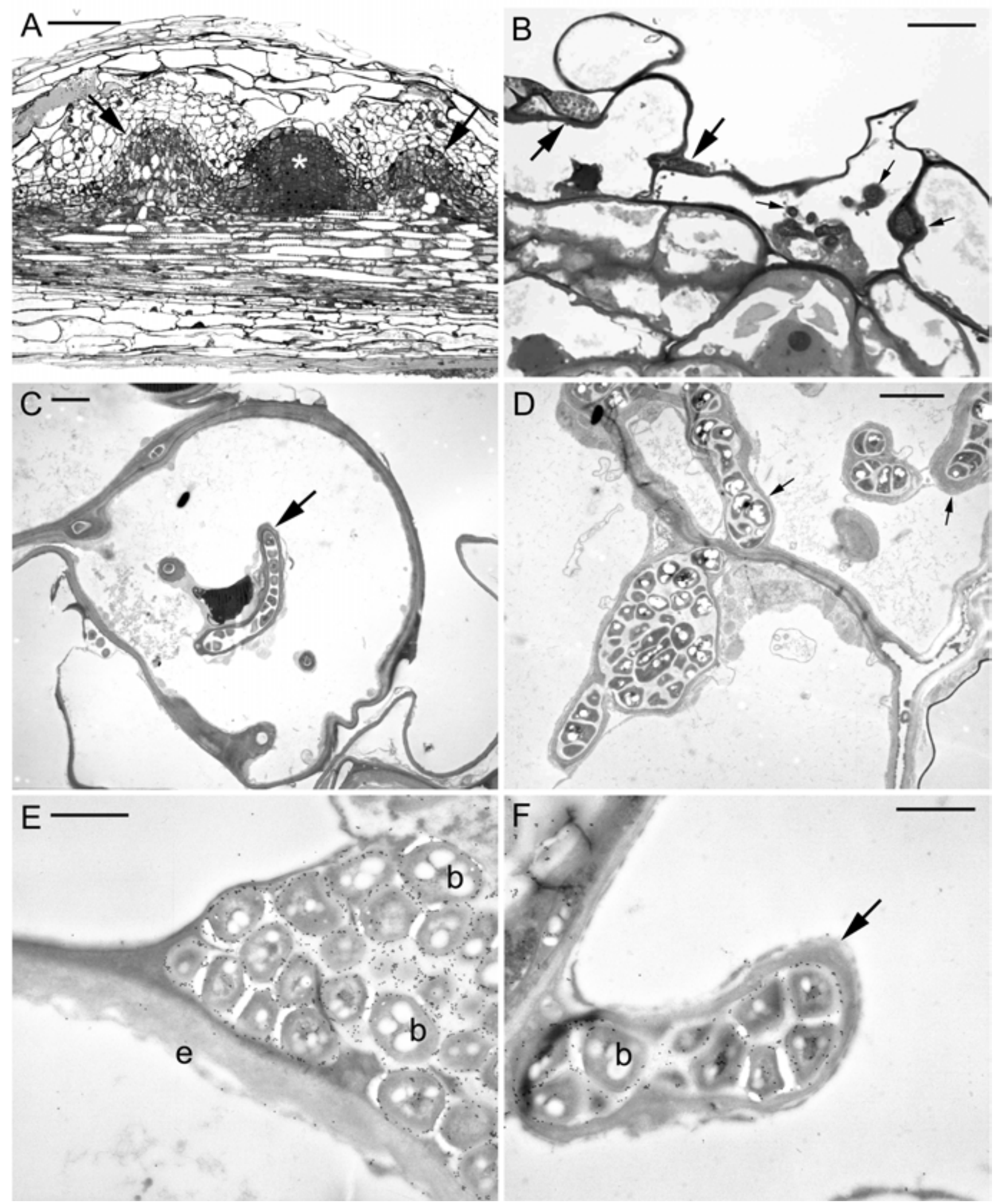

Fig. 5. A and B, Light microscopy and $\mathbf{C}$ through $\mathbf{F}$, transmission electron microscopy of roots of Mimosa diplotricha (A, B, and E) and M. pudica (C, D, and F). The sections were taken from roots or nodules at 5 days (A, B and E) 10 days, or 15 days (C, D, and F) after inoculation with Ralstonia taiwanensis 204. A, A nodule primordium (*) can be seen developing between two lateral root primordia (arrows); B, bacteria (large arrow) can be seen on the root surface close to root hairs or epidermal cells that contain infection threads (small arrows). C, Infection threads (arrows) within a root hair cell and then D, penetrating through the outer epidermal cell layers of a root towards the developing nodule primordium. E, Bacteria (b) immunogold labeled with an antibody against the green fluorescent protein $(g f p)$ reporter gene can be seen on the root epidermis (e) close to the infected root hairs or epidermal cells shown in A. F, Bacteria (b) immunogold labeled with the $g f p$ antibody within an infection thread (arrow) in a root hair. Bar $=100 \mu \mathrm{m}$ in A, $10 \mu \mathrm{m}$ in B, 2 $\mu \mathrm{m}$ in $\mathrm{C}$ and $\mathrm{D}$, and $1 \mu \mathrm{m}$ in $\mathrm{E}$ and $\mathrm{F}$. 

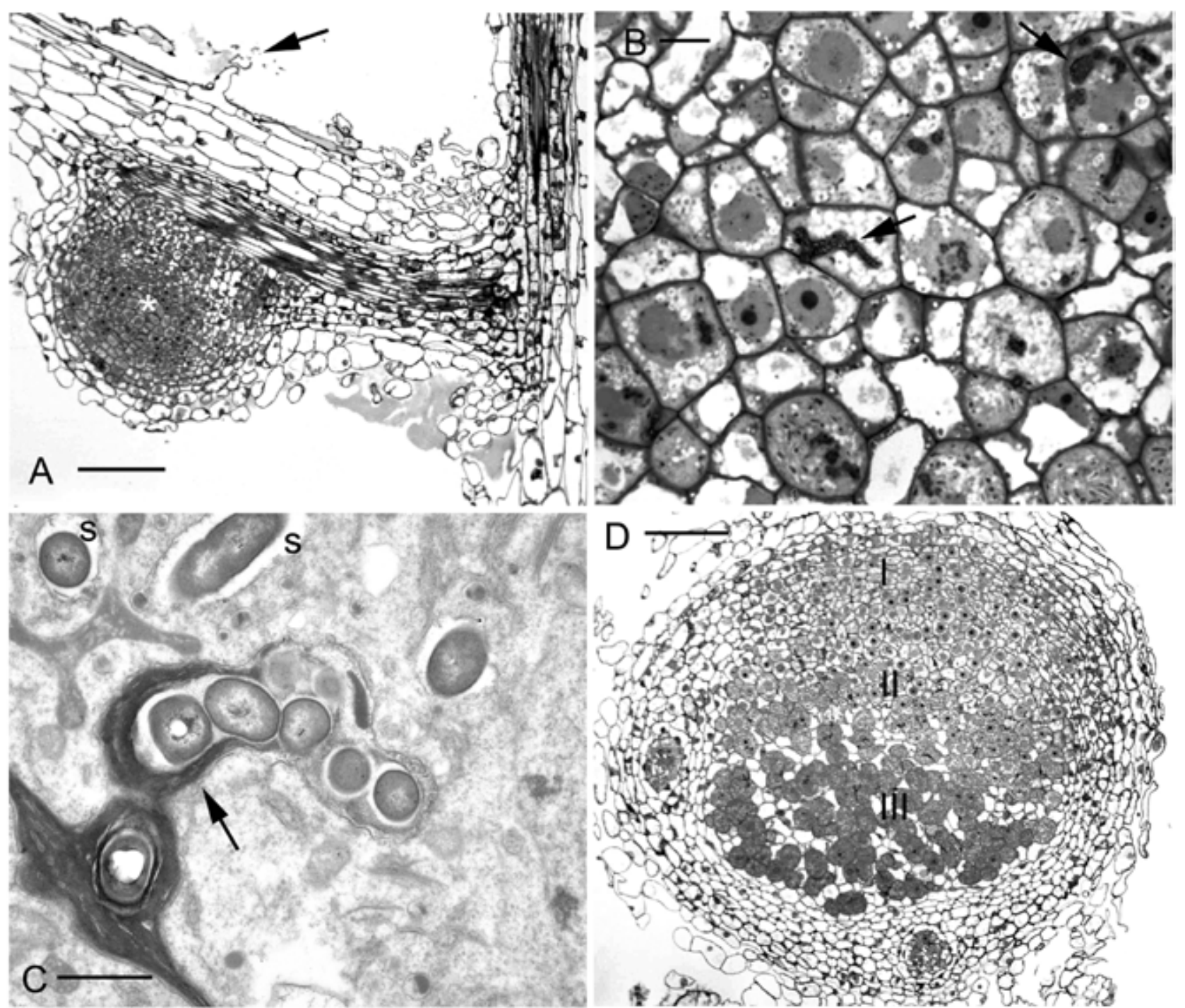

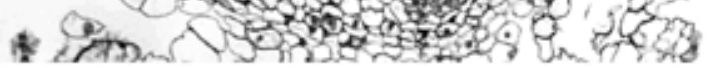

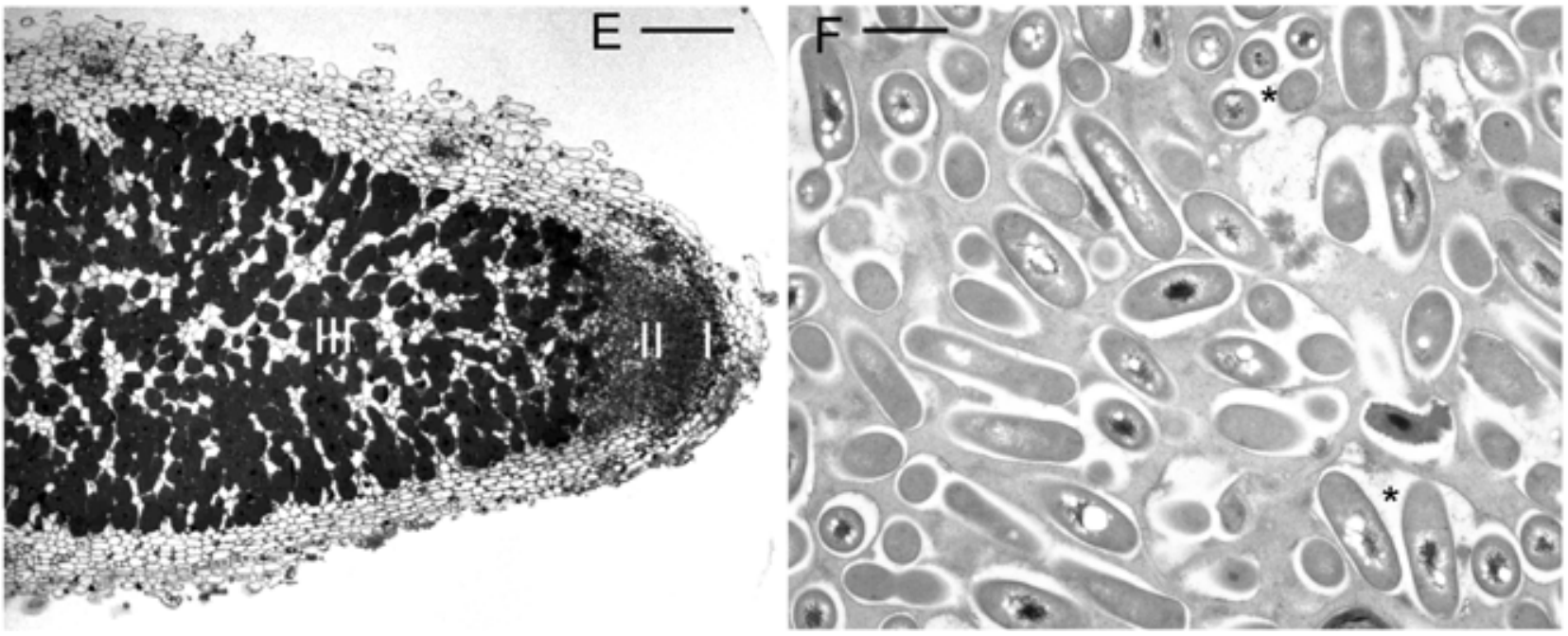

Fig. 6. A, B, D, and E, Light microscopy and $\mathbf{C}$ and $\mathbf{F}$, transmission electron microscopy of nodules of $\mathbf{E}$ and $\mathbf{F}$, Mimosa diplotricha and $\mathbf{A}$ through $\mathbf{D}, M$. pudica at 10 (A), 15 (B through D), or 30 days (E and F) after inoculation with Ralstonia taiwanensis 204. A, Initially, the nodule primordium (*) is a spherical mass of meristematic cells, often with a curled root hair close by (arrow). B and $\mathbf{C}$, Upon infection by the bacteria, the newly divided cells of the primordium are invaded by infection threads (arrows) that release bacteria singly into membrane-bound symbiosomes (s) within the host cells (C). D, The spherical nodule primordium develops a persistent apical meristem (zone I) together with an invasion zone (zone II) and the beginnings of an N-fixing zone (III) (closest to the point of attachment to the subtending root). E, Older nodules become elongated and typically indeterminate, with easily discernible zones I, II, and III, the N-fixing cells in the latter having symbiosomes containing up to four bacteroids (* in F). Bar $=100 \mu \mathrm{m}$ in A and D, 10 $\mu \mathrm{m}$ in $\mathrm{B}, 1 \mu \mathrm{m}$ in $\mathrm{C}$ and $\mathrm{F}$, and $200 \mu \mathrm{m}$ in $\mathrm{E}$. 
nod $A B C$ genes) via multiple lateral gene transfer from $\alpha$-rhizobia (Moulin et al. 2002). This means that it is probable that many other "nonrhizobial" bacteria capable of nodulation await isolation from legume nodules, particularly those in the tropics, where many have yet to be characterized (Sprent 2001). Indeed, if the Mimosa-R. taiwanensis symbiosis demonstrated here, in which $R$. taiwanesis is by far the preferred symbiont of the pantropical species $M$. diplotricha and $M$. pudica (Chen et al. 2001; Moulin et al. 2002), is representative of tropical legumes, it may turn out that such nonrhizobial symbioses, such as those formed with " $\beta$-rhizobia" (Moulin et al. 2002), are even more abundant and widespread than conventional $\alpha$-rhizobial ones.

\section{MATERIALS AND METHODS}

Bacterial strains and plasmids.

Bacterial strains and plasmids are listed in Table 1. R. taiwanensis LMG19424 was grown in yeast extract mannitol (YEM) medium (Vincent 1970) at $28^{\circ} \mathrm{C}$, and Escherichia coli strains were grown in Luria-Bertani medium at $37^{\circ} \mathrm{C}$. Antibiotics were used at the following final concentrations: tetracycline at $30 \mu \mathrm{g} \mathrm{ml}^{-1}$ for E. coli and R. taiwanensis; and kanamycin at 20 and $100 \mu \mathrm{g} \mathrm{ml}^{-1}$ for E. coli and R. taiwanensis, respectively.

\section{Conjugal transfer \\ of promoter-probing transposon through mating.}

Introduction of a promoter-probing transposon into $R$. taiwanensis LMG19424 was achieved by triparental mating. Equal amounts of the donor E. coli S17-1 $\lambda$ pir with pUTminiTn5gfp, helper E. coli HB101 with pRK2013, and recipient $R$. taiwanensis LMG19424 were mixed and spotted onto a nitrocellulose filter. After $24 \mathrm{~h}$ of incubation at $28^{\circ} \mathrm{C}$, the mating mixtures on the filter were washed and resuspended in sterile saline. The suspension was spread on selective plates of YEM medium with kanamycin at $100 \mu \mathrm{g} \mathrm{m}^{-1}$ and tetracycline at 30 $\mu \mathrm{g} \mathrm{ml} \mathrm{m}^{-1}$ at $28^{\circ} \mathrm{C}$ for 6 days. Bacterial colonies on solid media were exposed to blue light in a light box to check the expression of $g f p$. A Zeiss Axioskop microscope with Zeiss no. 9 and 15 filters and a 50-W type HBO high-pressure mercury lamp then were used to visualize $g f p$ expression by the bacteria, and strain 204 was selected for further studies.

\section{Plant material and growth conditions.}

$M$. pudica and $M$. diplotricha seed were surface sterilized with concentrated sulfuric acid for 10 min followed by $3 \%$ sodium hypochlorite for $10 \mathrm{~min}$. Seed were germinated on nutrient agar plates at $28^{\circ} \mathrm{C}$ in darkness to make sure there was no contamination. Plant cultivation and nodulation tests were carried out under sterile conditions using the tube method of Gibson (1963). The tubes contained a modified Jensens N-free plant nutrient medium (Somasegaran and Hoben 1994) and were incubated at $35^{\circ} \mathrm{C}$ under an irradiance of $400 \mu \mathrm{mol} \mathrm{m} \mathrm{m}^{-2} \mathrm{~s}^{-1}$ and a photoperiod of $16 \mathrm{~h}$. At 7 days after germination, the seedlings were inoculated with $100 \mu \mathrm{l}$ (approximately $10^{5}$ cells) of a washed suspension of either wild-type $R$. taiwanensis LMG19424 or the $g f p$ conjugate (strain 204). Plants were harvested at intervals up to 56 days from inoculation.

\section{Nitrogenase activity.}

Acetylene reduction assays were carried out on plants at 21 and 56 days after inoculation according to the method of James and Crawford (1998) using a gas chromatograph (Gow Mac Instrument Co., Shannon, Ireland) fitted with a series 752 flame ionization detector. Whole plants were inserted into a closed container (volume $=30 \mathrm{ml}$ for 21 -day and $800 \mathrm{ml}$ for 56-day plants) containing 10\% (vol/vol) acetylene, and 1-ml samples of the headspace gas were taken for analysis after a 1-h incubation.

\section{Preparation of bacterial and bacteroid extracts.}

Bacteria of either wild-type $R$. taiwanensis LMG19424 or the $g f p$ transconjugant (strain 204) were cultured in YEM broth (Vincent 1970) to late log phase. The bacteria were centrifuged at $10,000 \times g$ at $4^{\circ} \mathrm{C}$ for $10 \mathrm{~min}$, and the pellets washed twice in phosphate-buffered saline (PBS). Bacteroids were isolated by homogenizing nodules ( 0.5 to $1 \mathrm{~g}$ ) from 56-day $M$. diplotricha or $M$. pudica, inoculated with either wild-type $R$. taiwanensis LMG19424 or strain 204, using a glass mortar and pestle in $3 \mathrm{ml}$ of ice-cold PBS. The nodule extracts were washed with PBS containing $1 \%$ polyvinylpyrrolidone (PVP) and $1 \mathrm{mM}$ phenylmethylsulfonyl fluoride (PMSF), and the extracts were cleared by centrifugation at low speed $(500 \times g)$ at $4{ }^{\circ} \mathrm{C}$ for 3 min to eliminate larger cellular debris. The supernatant then was centrifuged at $5,000 \times g$ at $4^{\circ} \mathrm{C}$ for 5 min to pellet the bacteroids, which then were washed twice with PBS + PVP + PMSF. The bacterial and bacteroid pellets were resuspended in approximately $1 \mathrm{ml}$ of PBS containing $1 \mathrm{mM}$ PMSF and $5 \mathrm{mM}$ 1,4-dithiothreitol and sonicated five times (1 min with 1-min breaks) at $80 \%$ of the maximum energy setting $(1 \mathrm{~kW})$ in an ice-melting bath, after which the extracts were cleared by centrifugation at $30,000 \times g$ for $10 \mathrm{~min}$ at $4^{\circ} \mathrm{C}$. Finally, the supernatants were mixed with sample buffer (Laemmli 1970) and immersed in boiling water for $10 \mathrm{~min}$ before loading onto gels for electrophoresis.

\section{Sodium dodecyl sulfate-polyacrylamide gel electrophoresis and Western blotting.}

Sodium dodecyl sulfate-polyacrylamide gel electrophoresis on $10 \%$ polyacrylamide gels was performed according to the method described by Laemmli (1970) using a Bio-Rad Mini Protean III at a constant voltage of $140 \mathrm{~V}$ for $40 \mathrm{~min}$ at room temperature. Protein $(2 \mu \mathrm{g})$ was loaded per lane for nodule (bacteroid) samples, and $0.2 \mu \mathrm{g}$ for bacterial samples. Protein from the gels was transferred onto Immobilon-P membranes (Millipore Corp., Bedford, MA, U.S.A.) with a Bio-Rad MiniTrans-Blot Transfer Cell at a constant current of $400 \mathrm{~mA}$ using a transfer buffer containing $25 \mathrm{mM}$ Tris, $192 \mathrm{mM}$ glycine, and $20 \%$ (vol $/ \mathrm{vol}$ ) methanol. After blocking overnight in PBS + $0.5 \%(\mathrm{vol} / \mathrm{vol})$ Tween $20+5 \%$ (wt/vol) skim milk, the membranes were incubated for $1 \mathrm{~h}$ in a 1:1000 dilution (in the blocking solution) of a mouse monoclonal antibody (Roche Diagnostics Ltd., Lewes, U.K.) raised against $g f p$. The membranes were washed three times in $1 \mathrm{~h}$ in PBS $+0.5 \%$ Tween 20 and then incubated for $1 \mathrm{~h}$ in a 1:5000 dilution (in the blocking solution) of the secondary antibody (Pierce goat anti-mouse conjugated to horseradish peroxidase; Perbio Science UK Ltd., Tattenhall, U.K.). After further washing (three times in $1 \mathrm{~h}$ in PBS $+0.5 \%$ Tween 20), the membranes were probed for $1 \mathrm{~min}$ with the ECL+ Western blotting detection system (Amersham Biosciences UK Ltd., Little Chalfont, U.K.).

\section{Fluorescence microscopy.}

For localization of $g f p$ fluorescence, nodules were taken from Mimosa plants at 56 days after inoculation and sectioned on a Vibratome (Agar Scientific, Stansted, U.K.) to $100 \mu \mathrm{m}$. The sections then were mounted in Hydromount (National Diagnostics, Atlanta, GA, U.S.A.) on glass slides and viewed under a Zeiss LSM 410 laser scanning microscope using standard FITC filter settings (488-nm excitation and 515- to 530$\mathrm{nm}$ emission). Autofluorescence was judged by comparing the gfp image with the red fluorescence channel (543-nm excitation and $>570$-nm emission). 
Light and electron microscopy.

Nodules and pieces of nodulated roots were taken from Mimosa plants at various stages $(5,10,15,30,42$, and 56 days after inoculation) and fixed in $2.5 \%$ glutaraldehyde in $0.1 \mathrm{M}$ sodium cacodylate $(\mathrm{pH} 7.0)$ overnight at $4^{\circ} \mathrm{C}$. The fixed nodules and nodulated roots were either i) dehydrated in an ethanol series and embedded in LR White acrylic resin (James et al. 1996) for light microscopy and immunogold labeling (discussed below); ii) postfixed in $1 \%$ osmium tetroxide, dehydrated in an ethanol series, and then embedded in Durcupan epoxy resin (Sigma-Aldrich, St. Louis) for "conventional" TEM; or iii) progressively infiltrated in acetone, critical point dried in a Bal-Tec CPD 030 critical point drier (Balzers, Furstentum, Liechtenstein), and sputter-coated with $10 \mathrm{~nm}$ of gold-palladium in a Cressington 208 sputter coater (Cressington Scientific Instruments Ltd., Watford, U.K.) before being viewed under a Philips ESEM at an accelerating voltage of $15 \mathrm{kV}$.

Semithin $(1 \mu \mathrm{m})$ and ultrathin $(70 \mathrm{~nm})$ sections were taken from the resin-embedded samples (LR White and Durcupan) using a Reichert Ultracut E ultramicrotome. The semithin sections were collected on glass slides, and either used for immunogold labeling (discussed below) or stained with $1 \%$ toluidine blue in borax and viewed and photographed using an Olympus BH2 optical microscope. The ultrathin sections for conventional TEM were collected on pioloform-coated copper grids and stained with uranyl acetate $(10 \mathrm{~min})$ and lead citrate (5 $\mathrm{min}$ ) before being viewed under a JEOL $1200 \mathrm{EX}$ transmission electron microscope (JEOL, Tokyo). The TEM images were collected on phosphor imaging plates (DITABIS Digital Biomedical Imaging Systems AG, Pforzheim, Germany), which then were scanned on a DITABIS Micron High Resolution Imaging Plate Scanner. The data from each TEM image were stored as 40-megabyte TIFF files.

\section{Immunogold labeling.}

Ultrathin sections $(70 \mathrm{~nm})$ from LR White-embedded samples were collected as described above, but on nickel grids coated with pioloform. After blocking in a buffer containing $1 \%$ Tween 20 and $1 \%$ bovine serum albumin (IGL buffer) (James and Sprent 1999) the sections were immunogold labeled according to James and associates (1996) with dilutions (in IGL buffer) of antibodies raised against either $g f p$ (Abcam, Cambridge, U.K.) (diluted 1:200) or nifH protein (P. W. Ludden, Madison, WI) (diluted 1:100). After washing, 15-nm gold particles conjugated to goat anti-rabbit antibodies (BBInternational, Cardiff, U.K.) (diluted 1:100 in IGL buffer) were used to visualize the location of the primary antibody in each case. Samples were viewed under a JEOL 1200 EX transmission electron microscope. The following controls were performed for each immunogold assay: i) omission of the primary antibody and ii) substitution of the primary antibody by nonimmune sera diluted appropriately in IGL buffer.

Immunogold labeling and silver-enhancement of semithin sections for light microscopy were performed using the same antibodies as above, but 6-nm gold particles conjugated to protein A were used instead of the secondary antibody, because they gave more sensitivity when stained with silver. Silver enhancement of the sections was performed using the Amersham IntenseM kit according to the manufacturer's instructions.

\section{ACKNOWLEDGMENTS}

W.-M. Chen was supported by a grant from the National Science Council, Taiwan, R.O.C. (NSC 91-2320-B-127-001); and E. K. James by the Joint Infrastructure Fund (JIF), U.K. We thank M. B. T. Gruber for technical assistance, S. Swift for help with CLSM, L. Trinkle-Mulcahy for help with Western blots, and P. W. Ludden (Madison, WI) for the nitrogenase antibody.

\section{LITERATURE CITED}

Aguilar, N. O., Pitargue, F. C., and Cajano, M. O. 1994. Nodulation of legumes in the Philippines. Pages 25-31 in: Advances in Legume Systematics 5: The Nitrogen Factor, J. I. Sprent and D. McKey, eds. Royal Botanic Gardens, Kew., London.

Allen, O. N., and Allen, E. K. 1981. The Leguminosae. A Source Book of Characteristics, Uses and Nodulation. The University of Wisconsin Press, Madison.

Baird, L. M., Virginia, R. A., and Webster, B. D. 1985. Development of root nodules in a woody legume, Prosopis glandulosa Torr. Bot. Gaz. 146:39-43.

Barrios, S., and Gonzalez, V. 1971. Rhizobial symbioses on Venezuelan savannas. Plant Soil 34:707-19.

Boyer, H. W., and Roulland-Dussoix, D. 1969. A complementation analysis of the restriction and modification of DNA in Escherichia coli. J. Mol. Biol. 14:459-472.

Campêlo, A. B., and Campêlo, C. R. 1970. Eficiência da inoculacao cruzada entre espêcies da subfamília Mimosoideae. Pesqui. Agropecu. Bras. 5:333-337.

Chalfie, M., Tu, Y., Euskirchen, G., Ward, W. W., and Prasher, D. C. 1994. Green fluorescent protein as a marker for gene expression. Science 263:802-805.

Chen, H., and Rolfe, B. G. 1988. Rhizobium infection of Leucaena leucocephala via the formation of infection threads in curled root hairs. J. Plant Physiol. 332:379-382.

Chen, W.-M., Laevens, S., Lee, T. M., Coenye, T., De Vos, P., Mergeay, M., and Vandamme, P. 2001. Ralstonia taiwanensis sp. nov., isolated from root nodules of Mimosa species and sputum of a cystic fibrosis patient. Int. J. Syst. Evol. Microbiol. 51:1729-1735.

Cheng, H.-P., and Walker, G. C. 1998. Succinoglycan is required for initiation and elongation of infection threads during nodulation of alfalfa by Rhizobium meliloti. J. Bacteriol. 180:5183-5191.

de Faria, S. M., and de Lima, H. C. 1998. Additional studies of the nodulation status of legume species in Brazil. Plant Soil 200:185-192.

de Faria, S. M., de Lima, H. C., Franco, A. A., Mucci, E. S. F., and Sprent, J. I. 1987. Nodulation of legume trees from South East Brazil. Plant Soil 99:347-356.

de Faria, S. M., Hay, G. T., and Sprent, J. I. 1988. Entry of rhizobia into roots of Mimosa scabrella Bentham occurs between epidermal cells. J. Gen. Microbiol. 134:2291-2296.

de Faria, S. M., Lewis, G. P., Sprent, J. I., and Sutherland, J. M. 1989. Occurrence of nodulation in the Leguminosae. New Phytol. 111:607-619.

de Lorenzo, V., Herrero, M., Jakubzik, U., and Timmis, K. N. 1990. MiniTn5 transposon derivatives for insertion mutagenesis, promoter probing, and chromosomal insertion of cloned DNA in gram-negative eubacteria. J. Bacteriol. 172:6568-6572.

Ditta, G., Stanfield, S., Corbin, D., and Helinski, D. R. 1980. Broad host range DNA cloning system for gram-negative bacteria: construction of a gene bank of Rhizobium meliloti. Proc. Natl. Acad. Sci. U.S.A. 77:7347-7351.

Estrada de Los Santos, P., Bustillos-Cristales, R., and Caballero-Mellado, J. 2001. Burkholderia, a genus rich in plant-associated nitrogen fixers with wide environmental and geographic distribution. Appl. Environ. Microbiol. 67:2790-2798.

Gage, D. J., Bobo, T., and Long, S. R. 1996. Use of green fluorescent protein to visualize the early events of symbiosis between Rhizobium meliloti and alfalfa (Medicago sativa). J. Bacteriol. 178:7159-7166.

Gibson, A. H. 1963. Physical environment and symbiotic nitrogen fixation. I. The effect of root temperature on recently nodulated Trifolium subterraneum L. plants. Aust. J. Biol. Sci. 16:28-42.

Gross, E., Cordeiro, L., and Caetano, F. H. 2002. Nodule ultrastructure and initial growth of Anadenanthera peregrina (L.) Speg. Var. falcata (Benth.) Altschul plants infected with rhizobia. Ann. Bot. 90:175-183.

Jaftha, J. B., Strijdom, B. W., and Steyn, P. L. 2002. Characterization of pigmented methylotrophic bacteria which nodulate Lotononis bainesii. Syst. Appl. Microbiol. 25:440-449.

James, E. K., and Crawford, R. M. M. 1998. Effect of oxygen availability on nitrogen fixation by two Lotus species under flooded conditions. J. Exp. Bot. 49:599-610.

James, E. K., Iannetta, P. P. M., Nixon, P. J., Whiston, A. J., Peat, L., Crawford, R. M. M., Sprent, J. I., and Brewin, N. J. 1996. Photosystem II and oxygen regulation in Sesbania rostrata stem nodules. Plant Cell Environ. 19:895-910.

James, E. K., Loureiro, M., de F., Pott, A., Pott, V. J., Martins, C. M., Franco, A. A., and Sprent, J. I. 2001. Flooding-tolerant legume symbioses from the Brazilian 1; Pantanal. New Phytol. 150:723-738. 
James, E. K., Minchin, F. R., Iannetta, P. P. M., and Sprent, J. I. 1997. Temporal relationships between nitrogenase and intercellular glycoprotein in developing white lupin nodules. Ann. Bot. 79:493-503.

James, E. K., and Sprent, J. I. 1999. Development of $\mathrm{N}_{2}$-fixing nodules on the wetland legume Lotus uliginosus exposed to conditions of flooding. New Phytol. 142:219-231.

James, E. K., Sprent, J. I., Sutherland, J. M., McInroy, S. G., and Minchin F. R. 1992. The structure of nitrogen fixing root nodules on the aquatic Mimosoid legume Neptunia plena. Ann. Bot. 69:173-180.

Laemmli, U. K. 1970. Cleavage of structural proteins during the assembly of the head of bacteriophage T4. Nature 227:680-685.

Lechtova-Trnka, M. 1930. Etude sur les bactéries des Légumineuses et observations sur quelques champignons parasites des nodosités. Le Botaniste 23:301-530.

Lopez-Lara, I. M., Orgambide, G., Dazzo, F. B., Olivares, and J., Toro, N. 1993. Characterization and symbiotic importance of acidic extracellular polysaccharides of Rhizobium sp. strain GRH2 isolated from Acacia nodules. J. Bacteriol. 175:2826-2832.

Loureiro, M. F., James, E. K., and Franco, A. A. 1998. Nitrogen fixation by legumes in flooded regions. Oecol. Bras. 4:191-219.

Matthysse, A. G., Stretton, S., Dandie, C., McClure, N. C., and Goodman, A. E. 1996. Construction of GFP vectors for use in gram-negative bacteria other than Escherichia coli. FEMS (Fed. Eur. Microbiol. Soc.) Lett. 15:87-94.

Moreira, F. M., da Silva, M. F, and de Faria, S. M. 1992. Occurrence of nodulation in legume species in the Amazon region of Brazil. New Phytol. 121:563-70.

Moreira, F. M. S., Gillis, M., Pot, B., Kersters, K., and Franco, A. A. 1993 Characterization of rhizobia isolated from different divergence groups of tropical Leguminosae by comparative polyacrylamide gel electrophoresis of their total proteins. Syst. Appl. Microbiol. 16:135-146.

Moulin, L., Chen, W.-M., Béna, G., Dreyfus, B., and Boivin-Massson, C 2002. Rhizobia: the family is expanding. Pages 61-65 in: Nitrogen Fixation: Global Perspectives. T. Finan, M. O’Brian, D. Layzell, K. Vessey, and W. Newton, eds. CAB International, Wallingford, U.K.

Moulin, L., Munive, A., Dreyfus, B., and Boivin-Masson, C. 2001. Nodulation of legumes by members of the $\beta$-subclass of Proteobacteria. Nature 411:948-950.

Ndoye, I., de Billy, F., Vasse, J., Dreyfus, B., and Truchet, G. 1994. Root nodulation of Sesbania rostrata. J. Bacteriol. 176:1060-1068

Norris, D. O. 1969. Observations on the nodulation status of rainforest Leguminous species in Amazonia and Guyana. Trop. Agric. 46:145-151.

Oyaizu, H., Matsumoto, S., Minamisawa, K., and Gamou, T. 1993. Distribution of rhizobia in leguminous plants surveyed by phylogenetic identification. J. Gen. Appl. Microbiol. 39:339-354.

Parveen, N., Webb, D. T., and Borthakur, D. 1996. Leucaena leucocephala nodules formed by a surface polysaccharide defective mutant of Rhizobium sp. strain TAL1145 are delayed in bacteroid development and nitrogen fixation. Mol. Plant-Microbe Interact. 9:364-372.

Pueppke, S. G., and Broughton, W. J. 1999. Rhizobium sp. strain NGR234 and $R$. fredii USDA257 share exceptionally broad, nested host ranges. Mol. Plant-Microbe Interact. 12:293-318.

Räsänen, L. A., Sprent, J. I., and Lindström, K. 2001. Symbiotic properties of sinorhizobia isolated from Acacia and Prosopis nodules in Sudan and Senegal. Plant Soil 235:193-210.

Rivas, R., Velázquez, E., Willems, A., Vizcaíno, N., Subba-Rao, N. S., Mateos, P. F., Gillis, M., Dazzo, F. B., and Martínez-Molina, E. 2002 A new species of Devosia that forms a unique nitrogen-fixing rootnodule symbiosis with the aquatic legume Neptunia natans. Appl. Environ. Microbiol. 68:5217-5222.

Saur, E., Carcelle, S., Guezennec, S., and Rousteau, A. 2000. Nodulation of legume species in wetlands of Guadeloupe (Lesser Antilles).
Wetlands 20:730-734.

Schaede, R. 1940. Die Knöllchen der adventiven Wasserwurzeln von Neptunia oleracea und ihre Bakteriensymbiose. Planta 31:1-21.

Sicardi de Mallorca, M., and Izaguirre-Mayoral, M. L. 1993. A comparative evaluation of the symbiotic $\mathrm{N}_{2}$-fixation and physiological performance of thirty six native legume species collected in a tropical savannah during the rainy and dry seasons. Symbiosis 16:225-247.

Somasegaran, P., and Hoben, H. J. 1994. Handbook for Rhizobia: Methods in Legume-Rhizobium Technology. Springer-Verlag, New York.

Sprent, J. I. 2001. Nodulation in Legumes. Royal Botanic Gardens, Kew, London.

Sprent, J. I., Geoghegan, I. E., Whitty, P. W., and James, E. K. 1996. Natural abundance of ${ }^{15} \mathrm{~N}$ and ${ }^{13} \mathrm{C}$ in nodulated legumes and other plants in the Cerrado and neighbouring regions of Brazil. Oecologia 105:440-446.

Subba Rao, N. S., Mateos, P. F., Baker, D., Pankratz, H. S., Palma, J. Dazzo, F. B., and Sprent, J. I. 1995. The unique root-nodule symbiosis between Rhizobium and the aquatic legume, Neptunia natans (L. f.) Druce. Planta 196:311-320.

Sy, A., Giraud, E., Jourand, P., Garcia, N., Willems, A., de Lajudie, P. Prin, Y., Neyra, M., Gillis, M., Boivin-Masson, C., and Dreyfus, B. 2001a. Methylotrophic Methylobacterium bacteria nodulate and fix nitrogen in symbiosis with legumes. J. Bacteriol. 183:214-220.

Sy, A., Giraud, E., Samba, R., de Lajudie, P., Gillis, M., and Dreyfus, B. 2001b. Certaines légumineuses du genre Crotalaria sont spécifiquement nodulées par une nouvelle espèce de Methylobacterium. Can. J. Microbiol. 47:503-508.

Trinick, M. J. 1980. Relationships amongst the fast-growing rhizobia of Lablab purpureus, Leucaena leucocephala, Mimosa spp., Acacia farnesiana and Sesbania grandiflora and their affinities with other rhizobial groups. J. Appl. Bacteriol. 49:39-53.

van Berkum, P., and Eardly, B. D. 2002. The aquatic budding bacterium Blastobacter denitrificans is a nitrogen-fixing symbiont of Aeschynomene indica. Appl. Environ. Microbiol. 68:1132-1136.

Vandamme, P., Goris, J., Chen, W.-M., de Vos, P., and Willems, A. 2002. Burkholderia tuberum sp. nov. and Burkholderia phymatum sp. nov., nodulate the roots of tropical legumes. Syst. Appl. Microbiol. 25:507512.

Vasse, J., de Billy, F., Camut, S., and Truchet, G. 1990. Correlation between ultrastructural differentiation of bacteroids and nitrogen fixation in alfalfa nodules. J. Bacteriol. 172:4295-4306.

Vasse, J., Frey, P., and Trigalet, A. 1995. Microscopic studies of intercellular infection and protoxylem invasion of tomato roots by Pseudomonas solanacearum. Mol. Plant-Microbe Interact. 8:241-251.

Vincent, J. M. 1970. A Manual for the Practical Study of Root-Nodule Bacteria. IBP Handbook 15. Blackwell Scientific Publications, Oxford.

Wang, E. T., Rogel, M. A., de los Santos, A. G., Martínez-Romero, J., Cevallos, M. A., and Martínez-Romero, E. 1999. Rhizobium etli bv. Mimosae, a novel biovar isolated from Mimosa affinis. Int. J. Syst. Bacteriol. 49:1479-1491.

Xi, C., Lambrecht, M., Vanderleyden, J., and Michiels J. 1999. Bi-functional $g f p$ - and $g u s A$-containing mini-Tn5 transposon derivatives for combined gene expression and bacterial localization studies. J. Microbiol. Methods 35:85-92.

Yabuuchi, E., Kosako, Y., Yano, I., Hotta, H., and Nishiuchi, Y. 1995. Transfer of two Burkholderia and an Alcaligenes species to Ralstonia gen nov.: proposal of Ralstonia pickettii (Ralston, Palleroni and Doudoroff 1973) cob. Nov., Ralstonia solanacearum (Smith 1896) comb. nov. and Ralstonia eutropha (Davis 1969) comb. nov. Microbiol. Immunol. 39:897-904. 